\title{
Możliwości rozwoju kreatywności i innowacyjności - znaczenie otoczenia społecznego i nowych technologii
}

\section{Possibilities for developing creativity and innovation - the significance of social environment and new technologies}

\author{
Katarzyna Gurmińska \\ Wojskowa Akademia Techniczna \\ Wydział Cybernetyki
}

\begin{abstract}
Abstrakt. W artykule przeprowadzono analizę problemu rozwoju kreatywności i innowacyjności. W pierwszej jego części dokonano próby opisania kreatywności i innowacyjności oraz ukazania zależności między nimi. Położono nacisk na dwa ważne obecnie dla kreatywności czynniki: otoczenie społeczne i nowe technologie. Następnie opisano oddziaływanie otoczenia społecznego na kreatywność oraz edukacji na kształtowanie pozytywnych postaw wobec twórczości. W części końcowej zwrócono uwagę na pozytywne i negatywne konsekwencje cyfryzacji.

Słowa kluczowe: psychologia zarządzania, psychologia twórczości, kreatywność, innowacyjność

Abstract: The article presents an analysis of creativity and innovation development. First, an attempt was made to describe creativity and innovation and to show the dependencies between them. Emphasis is placed on two factors that are important today for creativity: the social environment and new technologies. The impact of the social environment on creativity and education on shaping positive attitudes towards creativity has been described. Noted the positive and negative effects of digitalization.

Keywords: psychology management, psychology of creativity, creativity, innovation
\end{abstract}

\section{Wstęp}

Współczesne organizacje muszą zmierzyć się ze zjawiskiem zmiany wpływu czynników, które mają obecnie znaczenie dla działania tychże organizacji. Ważnymi uwarunkowaniami stają się wzrost oddziaływania informacji poprzez rozwój nowych 
technologii oraz modyfikacje kapitału ludzkiego. Obecnie największe znaczenie dla potencjału ludzkiego ma kreatywność pracowników (Brzeziński, 2009, Szopiński, 2013; Daniecki, 2015). W nawiązaniu do tych uwarunkowań w artykule zadano pytanie o możliwości rozwoju kreatywności i innowacyjności. Dodać należy, że rozważania dotyczące zmian w kreatywności i związanej z nią innowacyjności prowadzone są w odniesieniu do dwóch czynników: znaczenia nowych technologii i cyfryzacji oraz kreatywności ludzkiej.

W związku z wejściem na rynek pracy pokoleń, dla których korzystanie z nowych technologii jest czymś naturalnym, pojawiło się pytanie o znaczenie cyfryzacji dla kreatywności. Zainteresowania badawcze autorki skupiają się na możliwościach uczenia kreatywności. W związku z obserwacjami poczynionymi w toku uczenia kreatywności ludzi dorosłych pojawiło się pytanie o znaczenie edukacji i wpływu otoczenia społecznego dla kreatywności. Niniejszy artykuł powstał jako odpowiedź na wiele głosów krytykujących niski poziom innowacyjności polskiej gospodarki i nawołujących do zmiany tego stanu. Celem artykułu jest wskazanie czynników najważniejszych dla rozwoju kreatywności i innowacyjności (z punktu widzenia nowych technologii oraz otoczenia społecznego). Wiedza o tym, jak owe czynniki wpływają na kreatywność i w dalszej kolejności na innowacyjność może skutkować oszacowaniem możliwości wykorzystywania nowych technologii i świadomego ich używania oraz wprowadzenia zmian w obszarze edukacji. Zdefiniowanie uwarunkowań i potrzeb związanych z tworzeniem takiego środowiska i otoczenia, w którym jest szansa na wzrost kreatywności, może mieć znaczenie dla niwelowania negatywnych aspektów i wzmacniania pozytywnych kontekstów. W pierwszej części artykułu wyjaśniono pojęcia „kreatywność” i „innowacyjność” oraz określono poziom innowacyjności i podano czynniki mające na nią wpływ. W drugiej części została podjęta próba opisania sposobu oddziaływania otoczenia społecznego na kreatywność i edukacji szkolnej prowadzonej tak, aby pozytywnie wpływała na kształtowanie pozytywnych postaw wobec kreatywności i innowacyjności. Część trzecia skupia się na roli nowych technologii i możliwości ich zastosowania w celu pobudzania kreatywności.

\section{Zależności między kreatywnością a innowacyjnością}

Kreatywność nie jest pojęciem jednoznacznym (Brzeziński, 2009; Szmidt, 2013; Szopiński, 2013). Wynika to z wielu definicji kreatywności, różnorodnych podejść i zamiennego stosowania terminu „kreatywność” i „twórczość” (Taylor, 1988; Szopiński, 2013; Nęcka, 2005a). Badania nad kreatywnością wynikają z badań prowadzonych na polu psychologii twórczości (Taylor, 1988; Nęcka, 2005a; Szopińska, 2013). Kreatywność to, w najprostszym ujęciu, pomysłowość, czyli zdolność do wytwarzania nowych idei, pomysłów czy rozwiązań (Sloane, 2005; Prelipcean, 2000; De Bono, 2011; Szmidt, 2013). Kreatywność prowadzi do innowacji, czyli 
zastosowania pomysłu w praktyce. Innowacyjność rozumiana jako możliwość stymulowania innowacji jest wynikiem kreatywności (West, 2000; Brzeziński, 2015). Brzeziński odwołuje się do pojęcia kapitału kreatywności indywidualnej, zespołowej i organizacyjnej (Brzeziński, 2015, s. 34-35). Bariery dotyczące uruchomienia wszystkich tych kapitałów, które mają prowadzić do innowacyjności, są szeroko opisywane w literaturze i skupiają się na jednostce, pracy grupowej oraz organizacji jako systemu. Dodatkowo jako czynnik wpływający na kreatywność należałoby dodać otoczenie społeczne, czyli społeczeństwo, w jakim funkcjonują jednostki i organizacje. Nęcka odwołuje się do pojęcia „kreatogennego” społeczeństwa (Nęcka, 2005, s. 157). Aspekty społeczne poszerzane są przez kontekst kulturowy, który także ma wpływ na kreatywność. Takie społeczeństwo, sprzyjając rozwojowi kreatywności, wpływałoby na kreatywność poszczególnych jego członków.

W celu stworzenia innowacyjnej gospodarki, która zależy od kapitału pracowników, organizacji oraz zespołów w tych organizacjach, należy zacząć od kreatywności jednostek. Pomysłowość nie jest cechą przypadkową. Osoby, które mają interesujące idee, najpierw ich poszukują. Pomysłowość wynika z dociekliwości, zaangażowania i wytrwałości w poszukiwaniu możliwości, nowości, odmiennych od dotychczasowych rozwiązań, ulepszeń czy wynalazków (Proctor, 2003, s. 21-22). Wysoki poziom kreatywności, czyli wiele osób kreatywnych w społeczeństwie, powinien mieć pozytywny wpływ na innowacyjność w różnych obszarach, czy będzie to sztuka, gospodarka, czy codzienne rozwiązywanie problemów. Pierwszą ważną kwestią jest poziom kreatywności w społeczeństwie, drugą - innowacyjność.

Komisja Wspólnot Europejskich w 2009 roku opublikowała komunikat, w którym zawarła potrzebę rozwoju młodzieży poprzez stwarzanie jej większych możliwości w ośmiu obszarach działania. Jednym z nich była „Kreatywność i przedsiębiorczość”. Rozwój w tym obszarze był realizowany poprzez promowanie zdolności kreatywnego myślenia, które powinno przejawiać się w przedsiębiorczości oraz w uczestnictwie w kulturze (Komisja Wspólnot Europejskich, 2009, s. 8). W komunikacie wskazano na konieczność rozwijania kreatywnego podejścia w dążeniu do osiągnięcia innowacyjności. Młodzi ludzie wchodzący w dorosłe życie mogliby korzystać ze swojego potencjału na rzecz rozwoju gospodarki, nauki, kultury i sztuki. W dokumencie dostrzeżono i zaznaczono zależność między rozwojem kreatywności i jej wpływem na powstawanie innowacji.

Premier Beata Szydło w swym wystąpieniu na 26. Forum Ekonomicznym w Krynicy w 2016 roku położyła nacisk na kreatywność i innowacyjność, dzięki którym Polacy mogą być lepsi od innych (Sudak, 2016).

Postulaty podkreślające znaczenie kreatywności i innowacyjności w dzisiejszym świecie pojawiają się w wypowiedziach wielu osób z kręgów polityki i biznesu. Jednak samo pozytywne nastawienie do kreatywności i innowacyjności nie jest wystarczające dla ich rozwoju. Ważne jest, aby takie poglądy znajdowały wsparcie systemowe dla kreacji i innowacji. 
Kreatywność trudno jest badać w organizacjach, co jest spowodowane wpływem różnych czynników istotnych dla kreatywności, dynamiką i procesowością kreatywności. Dla odmiany innowacyjność jest mierzalna.

Raport Komisji Europejskiej z 2016 roku dotyczący innowacyjności plasuje Polskę na 24. miejscu na 29 państw Unii Europejskiej, z których pochodziły dane zebrane na potrzeby raportu (Komisja Europejska, 2016a). Innowacyjność w Polsce w latach 2008-2015 wzrosła o 0,1\%. W tym samym czasie największy wzrost miał miejsce na Litwie - 4\%. Polska znalazła się wśród państw określanych mianem "moderate innovators” (Komisja Europejska, 2016b). Jednocześnie nie została umieszczona w gronie państw szybko zwiększających swoją innowacyjność.

Opierając się na przedstawionych danych, warto zwrócić uwagę na rozumienie pojęcia wzrostu innowacyjności. W państwach i regionach, $w$ których następuje wzrost innowacyjności lub utrzymuje się ona na stałym poziomie, charakterystyczna jest dbałość o jej rozwój. Przejawia się to udzielaniem wsparcia dla inwestycji, dbałościa o edukację, odpowiednie warunki pracy oraz uznanie dla przedsiębiorczości i innowacyjności ze strony administracji. Unia Europejska udziela wskazówek, jak stać się innowatorem. Przede wszystkim należy dążyć do stworzenia systemu innowacji, który będzie oznaczał współpracę różnych instytucji, a także dbałość o edukację i badania naukowe (Komisja Europejska, 2016a).

W Polsce często pojawiają się postulaty dotyczące potrzeby zwiększenia innowacyjności Polaków. Podsumowania z 2015 roku pokazują, że dla przedsiębiorców innowacje nie są najważniejsze. Takie podejście do innowacji może prowadzić do odrzucania kreatywności, nowych idei, ciekawych pomysłów i do braku zainteresowania tym obszarem. Jeśli nawet pracownicy przedsiębiorstw mają interesujące pomysły, mogą one zostać ocenione negatywnie i odrzucone.

W rankingu globalnej konkurencyjności Światowego Forum Ekonomicznego 2014-2015 Polska w zakresie innowacji zanotowała spadek o 7 pozycji - na miejsce 72. w gronie 144 państw. W wielu wskaźnikach charakteryzujących konkurencyjność Polska radzi sobie dobrze, lecz ten, który jest ważny dla rozwoju gospodarki, nie znajduje się na satysfakcjonującym poziomie (Ministerstwo Gospodarki, 2015, s. 95).

Powyższe dane świadczą o tym, że postulaty o potrzebie innowacyjności nie znajdują odzwierciedlenia w postawie wobec kreatywności, a także uwidaczniają brak szeroko rozumianego wsparcia systemowego dla innowacyjności. Na potrzeby niniejszego artykułu omówione zostaną dwa rodzaje wpływu na kreatywność, a $\mathrm{w}$ dalszej kolejności na innowacyjność. Pierwszy związany jest $\mathrm{z}$ otoczeniem społecznym, drugi wynika z życia w świecie nowych technologii. 


\section{Wpływ otoczenia społecznego na kreatywność}

Wpływ otoczenia społecznego na postawy wobec kreatywności i innowacji wiąże się z postawą wobec twórczości. Czy twórczość jest obecnie doceniana, zarówno w wymiarze artystycznym, jak i w biznesie czy pracy? Dodatkową kwestią są wiedza i edukacja w Polsce, które oddziałują na młode osoby. W jakim stopniu edukacja w Polsce wpływa na kreatywność dzieci i młodzieży? Pobudza i inspiruje czy też blokuje i hamuje możliwości kreatywne?

Amabile uważa, że na kreatywność składa się kompilacja kilku czynników (Amabile, 2012, s. 3-4). Po pierwsze, umiejętności związane z daną dziedziną, takie jak wiedza, znajomość tejże dziedziny i talent jej dotyczący, inteligencja oraz uzdolnienia techniczne. Po drugie, procesy wpływające na kreatywność, do których należą styl poznawczy oraz osobowość. Otwartość, samodyscyplina, elastyczność, umiejętność przełamywania schematów myślowych - to cechy istotne dla kreatywności. Po trzecie, motywacja. Osoby kreatywne kierują się motywacją wewnętrzną. Dla nich rozwiązanie problemu jest zadaniem, które traktują jak wyzwanie. Poradzenie sobie $z$ sytuacją problemową daje im satysfakcję, samo zaś dochodzenie do rozwiązania jest przyjemne i doświadczają w związku z tym dużo pozytywnych emocji. Czwartym, ostatnim czynnikiem mającym wpływ na kreatywność jest otoczenie społeczne. Środowisko społeczne, wpływając z zewnątrz, nie powinno niszczyć motywacji wewnętrznej, co bardzo łatwo jest uczynić.

Niewątpliwie dla tworzenia niezbędna jest wiedza. Dodatkowym czynnikiem istotnym dla powstawania nowości są postawy (własne oraz otaczających osób), które pobudzają i rozwijają nastawienie twórcze. Dzięki temu możliwe jest przełamywanie oporów i przeciwdziałanie różnego rodzaju hamulcom (Antoszkiewicz J.D, Antoszkiewicz E.A, Piech, 2005, s. 164). Postawa jest stosunkowo trwałym stosunkiem do obiektu postawy (Migdał, 2003, s. 318). Postawa twórcza będzie oznaczała pozytywne nastawienie wobec kreatywności. Tworzenie, wymyślanie nowych rozwiązań, dążenie do udoskonalania już istniejących jest wartościowe i nacechowane pozytywnie emocjonalnie. Wytwarzanie takiej postawy u dzieci i młodzieży będzie w przyszłości procentować większą ich otwartością na nowości oraz chęcią ich wspierania.

Wielu mikroprzedsiębiorców nie inwestuje w innowacyjność. Ukształtowane wcześnie (w okresie edukacji szkolnej) postawy wobec twórczości, wobec własnej kreatywności i innowacji mogą mieć znaczenie dla późniejszych zachowań znamionujących kreatywność. Negatywna postawa może wynikać z doświadczeń i powodować odrzucanie kreatywności własnej i innych osób. Wielu autorów zgadza się z tym, że otoczenie wpływa na kreatywność (Nęcka, 2005a; Amabile, Pillemer, 2011). Otoczenie społeczne będzie stanowić w pierwszym rzędzie rodzina, środowisko szkoły, rówieśnicy, a następnie środowisko pracy oraz społeczeństwo związane z przynależnością do danego państwa oraz społeczeństwo sieciowe. Społeczeństwo 
sieciowe jest nowym doświadczeniem i oznacza zmianę w społecznych interakcjach. Najważniejsze w takim społeczeństwie staje się przesyłanie obrazów i wiadomości (Castells, 2008, s. 474).

Ta łączność społeczna stwarza szansę kontaktów z dużą liczbą różnych osób, uczestniczenia w odmiennych kulturach i docierania do informacji wcześniej niedostępnych. Te wszystkie czynniki mogą pobudzać kreatywność.

Kontekst kulturowy i społeczny wpływa szerzej na kreatywność, oddziałując na ludzi, którzy są mu poddani. W świecie społeczeństwa sieciowego staje się ono otoczeniem pobudzającym zachowania twórcze i zwiększające kreatywność. Warunki społeczne pomagające w rozwijaniu kreatywności to: dobrobyt, wolność osobista, różnorodność kulturowa oraz pozytywna ocena kreatywności jako wartości (Nęcka, 2005, s.158-159). Różnorodność kulturowa zapewniona jest przez korzystanie z nowych technologii. Natomiast kreatywność traktowana jako wartość tworzy postawę wobec twórczości i innowacji. Postawy kształtowane są w dzieciństwie i mogą wykazywać się trwałością (Migdał, 2003, Zimbardo 2009). Postawy wytworzone w nowych pokoleniach są bardzo istotne dla promowania kreatywności, a wpływ na młodego człowieka ma przede wszystkim środowisko rodzinne i szkoła.

Dla działań kreatywnych ważna jest motywacja wewnętrzna, którą pobudzają poznawanie oraz doznania związane z nowymi obiektami. Te warunki spełniają nowe technologie, dostarczające ludziom stymulacji. Chcąc pobudzać kreatywność ludzi, należy zapewnić im specyficzne zadania. Sam dostęp do wiedzy oraz uczenie się nowego nie zagwarantują wykształcenia postawy kreatywnej. Istotnym czynnikiem są stawiane przed człowiekiem wyzwania związane z jego kompetencjami oraz zadania, jakie on sam sobie wyznacza. Tutaj ważną rolę odgrywa system edukacji, który może mieć wpływ na postawy twórcze uczniów, dając im sygnał, co jest akceptowane (wysokie oceny), a co nie (niskie oceny). Różnorodne zadania w szkołach (projekty) mogą dawać takie możliwości, ale testy, jednomyślność odpowiedzi - już nie.

Postawy wobec kreatywności u osób dorosłych często są już ukształtowane (jak wiele innych postaw), ale mogą oddziaływać na postawy innych, młodszych ludzi, w szkole i w pracy. Otoczenie społeczne może wpływać na posiadaną przez daną osobę wiedzę oraz umiejętności związane z kreatywnością (Amabile, 2012, s. 15). Wszystko to można ukształtować i wytrenować. Człowiek przebywający w środowisku sprzyjającym kreatywności będzie miał szansę pobudzać i zwiększać swoje zdolności. Osoba poddana wpływom otoczenia hamującego kreatywność może od takiego zachowania odchodzić i porzucać je na rzecz innego, które jest aprobowane przez ludzi wokół niej.

Postawa wobec kreatywności kształtowana przez otoczenie społeczne będzie związana zarówno z domem, jak i ze szkołą. Kwestie rodzinne są indywidualne, natomiast szkoła jest szerszym, ogólnym systemem, który, poprzez swoją masowość, może oddziaływać na wszystkich w podobny sposób. 
Edukacja sprzyjająca kreatywności powinna obejmować samodzielność ucznia, jego aktywne działania, czyli nastawienie na poszukiwanie, a nie odtwarzanie, indywidualne podejście do ucznia oraz uczenie postawy twórczej (Stanisławiak, 2013, s. 1479). Współcześnie w tym zakresie pomocne mogą być nowe technologie.

Badania pokazują, że wpływ szkoły jest zróżnicowany (Karwowski, Jankowska, 2015, s. 67). Rodzaj oddziaływania zależy od środowiska szkolnego i postaw w nim panujących. W szkołach, gdzie ceni się twórczą aktywność, zajęcia będą prowadzone w taki sposób, aby angażować wyobraźnię i kłaść nacisk na kreatywność. Istnieją też szkoły, w których nauczyciele skupiają się raczej na zapamiętywaniu i odtwarzaniu wiedzy. Można przypuszczać, że są takie oddziały klasowe, gdzie twórcze myślenie i działanie ceni się bardziej, ale i takie, gdzie dominuje nauczanie według schematów i pamięciowe opanowywanie wiedzy. Uczniowie przebywający w środowisku promującym postawy pozytywne wobec kreatywności również będą przyjmowali takie postawy. Znaczenie dla rozwoju kreatywności będzie miał stosunek nauczyciela do kreatywności, nowości i odmienności oraz sposobu nauczania. Do opanowywania postaw kreatywnych oraz umiejętności tworzenia przydatne są mechanizmy uczenia się polegające na naśladowaniu, identyfikacji czy modelowaniu (Nęcka, 2005a; Stanisławiak, 2013). Szkoła jako system edukacji, czyli sposób kształcenia i oddziaływania, wpływa na kolejne pokolenia. To, jak funkcjonuje system, będzie oddziaływać na uczniów w nim przebywającym.

Patrząc w szerszym kontekście, warto skupić się na społeczeństwie. W Komunikacie Komisji do Rady Parlamentu Europejskiego, Europejskiego Komitetu Gospodarczo-Społecznego i Komitetu Regionów z 2006 roku zwrócono uwagę na stworzenie takiego środowiska $w$ Europie, w którym innowacja staje się „kluczową wartością" (Komisja Wspólnot Europejskich, 2006).

Rozpoczynające pracę nowe pokolenia, funkcjonujące od początku swojego życia w świecie nowych technologii i szybko przyswajające sobie nowości, współpracują z osobami w różnym wieku. Na młode osoby wpływ mają nauczyciele - indywidualnie, tworząc wzory do naśladowania. Kreatywni nauczyciele będą pobudzać swoich uczniów do kreatywności. Natomiast nawet najlepszy i najbardziej kreatywny czy otwarty nauczyciel nie zdziała tyle, co cały system edukacji. Tworzenie testów zaliczeniowych, podsumowujących każdy etap edukacji i wymaganie jednoznacznych odpowiedzi na zawarte w nich pytania nie tworzy klimatu sprzyjającego wymianie myśli, poglądów, uczenia się argumentowania, nie uczy otwartości i elastyczności w myśleniu, a raczej zamyka i blokuje możliwości. Uczniowie muszą udzielać odpowiedzi zgodnych z kluczem, nie ma więc miejsca na dyskusję i dopuszczanie odmiennych, różnorodnych poglądów. Później takie osoby, korzystając z internetu, prawdopodobnie nie będą przeglądać dużej liczby stron, gdzie miałyby do czynienia z różnymi, odmiennymi punktami widzenia, ale będą odwiedzać wyłącznie witryny zawierające podobne treści i prezentujące zbliżone idee, co będzie skutkowało 
silniejszym zamknięciem tychże osób i utwierdzeniem ich we własnych przekonaniach i iluzji jednomyślności i trafności wyznawanych poglądów.

Organizacje doceniają kreatywność, a przynajmniej na pewno na poziomie deklaratywnym, gdyż w wielu ogłoszeniach o pracę kreatywność pojawia się jako cecha pożądana u pracownika. Jednocześnie w różnych instytucjach często nie ma wsparcia dla kreatywności (Nęcka, 2005; Ridderstråle, Norsdström, 2006; Brzeziński, 2009; Szopiński, 2013). Powody niszczenia kreatywności w miejscu pracy są różne. Warunki powstawania kreatywnych rozwiązań stoją często w sprzeczności z praktyką menedżerską. Menedżerowie doceniają wprawdzie znaczenie kreatywności i innowacji, trudno jednak na co dzień tworzyć warunki dla jej podtrzymywania i rozwoju. Twórcze rozwiązania i pomysły wymagają czasu, gdyż są wynikiem procesu, który może być długotrwały i w trakcie którego trzeba się liczyć z porażkami. Nastawienie na szybki zysk i natychmiastowe rozwiązania nie tworzy przyjaznej atmosfery dla kreatywności, gdyż czasami trzeba wielu pomysłów, aby któryś okazał się innowacją.

Optymistycznie brzmią opinie niektórych autorów, że kreatywności można się uczyć w każdym wieku (Nęcka, 2005b; Stanisławiak, 2013; Szmidt, 2013). Dzięki temu każdy może rozwijać swoją otwartość poznawczą i elastyczność myślenia. W związku z tym ważne jest stworzenie środowiska sprzyjającego kreatywności, gdyż wtedy nawet osoby o niższym jej poziomie mogą stać się bardziej skłonne do przyjmowania postaw kreatywnych. Dlatego aktualnie ważne jest zwrócenie uwagi organizacjom na konieczność dbania o warunki sprzyjające kreatywności, ponieważ pozytywnym wynikiem tego podejścia będą innowacje.

\section{Znaczenie nowych technologii dla kreatywności i innowacyjności}

Czy nowe technologie mogą być pomocne w rozwoju kreatywności i innowacyjności? Nowoczesne społeczeństwo korzystające z nowych technologii zmienia się w porównaniu do społeczeństwa żyjącego w erze przemysłowej. Cechy myślenia charakterystyczne dla współczesności to poetyckość, myślenie skojarzeniowe i posługiwanie się metaforą (Eriksen, 2003, s. 155). Konsekwencje życia w takim społeczeństwie mogą być różnorodne. Przywołany rodzaj myślenia sprzyja kreatywności, gdyż asocjacje, metafory, wyobraźnia to kilka z umiejętności poznawczych w wykonywaniu operacji odpowiedzialnych za twórcze myślenie (Nęcka, 2005b, s. 49). W takim wypadku życie w dzisiejszym świecie nowych technologii może mieć pozytywny wpływ na kreatywne myślenie.

Można się zastanawiać, w jakim stopniu biznes i gospodarka korzystają z nowych technologii, sprzyjając w ten sposób kreatywności. Czy cyfryzacja pobudza kreatywność w biznesie i gospodarce? Czy tworzy warunki dla innowacyjności? 
Cyfryzacja daje szansę na rozwój innowacyjności, gdyż technologia informacyjna sama jest innowacją. Stanowi także podstawę, na której bazują kolejne innowacje (Niedzielski, Rychlik, 2007, s.22-23).

Niewątpliwie ważną kwestią dla korzystania $\mathrm{z}$ nowych technologii jest umiejętność posługiwania się nimi. W latach 2011-2012 przeprowadzono w 24 krajach badanie dotyczące kompetencji osób dorosłych. Jedną z badanych umiejętności było wykorzystywanie technologii informacyjno-komunikacyjnych (TIK). Okazało się, że w grupie badanych w wieku 16-24 lata nie ma różnic między młodymi Polakami a osobami innych nacji, natomiast Polacy z grupy do 65. roku życia na tle mieszkańców innych państw wypadają gorzej. Spadek kompetencji w tym zakresie obserwuje się szczególnie u osób starszych niż 30 lat (Burski et al., 2013, s. 5-7). Takie wyniki oznaczają, że pod względem możliwości wykorzystania technologii młodzi Polacy dorównują innym, można więc domniemywać, iż w tej grupie wiekowej wpływ technologii na kreatywność byłaby podobna. Większy problem jest $\mathrm{z}$ osobami starszymi. W tej grupie tylko wśród osób z wysokim wykształceniem nie ma różnic w porównaniu $\mathrm{z}$ osobami $\mathrm{z}$ państw wysoko rozwiniętych.

Brak dostępu do technologii i nieumiejętność korzystania z nich mogą powodować to, że część osób jest odcięta od różnorodnych informacji i wiedzy dostępnej przez internet. W związku z tym kreatywność może być cechą charakterystyczną bardziej dla młodego, wychowanego w erze internetu pokolenia, niż dla starszych generacji. Osoby starsze w wielu przypadkach nie mają nawet możliwości korzystania $\mathrm{z}$ różnorodnych, nowych obszarów. A młodzi ludzie, dla których nowe technologie są stałym elementem życia i środowiska, w którym egzystują, dopiero rozpoczynają swoją aktywność na rynku pracy, więc ich kreatywność może nie być jeszcze widoczna w gospodarce.

Jednym z czynników pobudzających rozwój kreatywności jest wiedza. Różnorodność informacji, łatwość jej pozyskiwania to zalety internetu. Niewątpliwie internet przyspiesza także uzyskiwanie informacji i zawiera ogromny zasób wiedzy. Jednak trudnością może być to, że jest on także pełen informacji, które nie podlegają selekcji czy uporządkowaniu. Pojawia się zatem pytanie o jakość wiedzy czerpanej $\mathrm{z}$ internetu. Ekspert, specjalista w danej dziedzinie potrafi szybko ocenić informacje, ich przydatność i jakość. Mimo to dotarcie do wartościowych i wiarygodnych informacji także jemu może zająć dużo czasu i pochłonąć sporo energii. Natomiast reszta osób, będąca laikami w określonej dziedzinie, może korzystać z wiedzy szczątkowej, przetworzonej i chaotycznej. Jak uważa Eriksen, jedną z umiejętności współczesnego człowieka powinna być umiejętność filtrowania informacji (Eriksen, 2003, s. 210). Obecnie wiedza staje się fragmentaryczna i powierzchowna, i w taki sposób jest też tworzona dla współczesnego odbiorcy, dla którego ważnymi kategoriami są czas i szybkość. Oddzielanie wiadomości przydatnych od chaosu informacyjnego jest ważną umiejętnością w dzisiejszym świecie nowych technologii. 
Zdolności poznawcze człowieka są ograniczone, nie jest on więc w stanie przebrnąć przez wiele stron, np. po wpisaniu w wyszukiwarkę Google hasła 'kreatywnośćc pojawia się około 6950000 wyników; hasło 'innowacyjność' ma wyników 3300000 (data badania: 19.07.2016). Wiele stron się powtarza, co sprzyja zwielokrotnianiu nieistotnych informacji. Strony interesujące, zawierające przydatną wiedzę, przeplatają się ze stronami nieciekawymi, pozbawionymi ważnych informacji. Nawet czasowo bywają one nieuporządkowane. Dotarcie do wiedzy wymaga zatem wytrwałości i umiejętności.

W tym wypadku nowe technologie pozwalają na nieograniczony dostęp do informacji, co ma pozytywne znaczenie dla kreatywności. Jednak istnieje też ciemna strona korzystania z takiej wiedzy, która może zawierać wiele fałszywych informacji i opierać się nie na faktach, a na przekonaniach. Wszystko będzie zależało od tego, kto i jak korzysta $\mathrm{z}$ wiedzy pochodzącej $\mathrm{z}$ internetu.

Nowe technologie sprzyjają kreatywności także w taki sposób, że różnorodne techniki rozwiązywania problemów mogą korzystać ze wsparcia informatycznego (Kąkol et al., 2013, s. 4072-4084, 4441-4494). Pomoc ta będzie obejmować wizualizacje, tworzenie diagramów, prezentacje rozwiązań, przeprowadzanie sesji rozwiązywania problemów on-line, tworzenie programów wspomagających daną technikę. W związku z tym nowe technologie będą pozytywnie wpływać na pracę twórczą.

Korzystanie z nowych technologii oznaczające brak ograniczeń i otwarcie na świat może też pomagać w poszerzaniu horyzontów i przełamywaniu barier myślowych. Zacierają się różne granice. Bardzo popularna w 2016 roku gra Pokemon Go umożliwia kontaktowanie się ludzi z całego świata, ponieważ ma zasięg globalny. Aplikacja zawiera nawet różne ciekawostki i informacje, które gracz może poznać, jeśli go zainteresują. Oprócz funkcji rozrywkowej gra może więc mieć także wartość poznawczą. Oczywiście wpływ w tym zakresie będzie zależał od otwartości osoby korzystającej z nowych technologii i jej motywacji do zdobywania wiedzy.

Na rynek pracy wchodzi coraz więcej osób obeznanych z nowymi technologiami i żyjących w środowisku sieciowym; można mówić, że na rynku pojawia się nowe pokolenie przyzwyczajone do innego funkcjonowania. Zarówno szkoła, jak i praca powinny wykorzystywać nowe technologie w pozytywny sposób, aby wspierać kreatywność.

\section{Podsumowanie}

Można stwierdzić, że na rozwój kreatywności i innowacyjności należy patrzeć jako na problem złożony. Niektórzy autorzy skupiają się na pozytywnych aspektach kreatywności i innowacyjności. Współcześnie takie pozytywne znaczenie może mieć zwłaszcza cyfryzacja. Młode pokolenia żyjące w świecie nowych technologii wejdą w świat zróżnicowany, w którym kreatywność niekoniecznie jest wartością 
promowaną. Rozwój kreatywności można hamować i niszczyć, zatem również młodzi ludzie mogą odchodzić od twórczych działań. Aktualnie otoczenie społeczne (kultura) wraz z nowymi technologiami sprzyjają kreatywności. Obecnie w przestrzeni publicznej więcej mówi się o innowacyjności, którą się postuluje, niż o kreatywności. Kreatywność stanowi bazę dla innowacji. Element edukacyjny w organizacjach i społeczeństwie powinien być ukierunkowany na uczenie kreatywności, pobudzania jej i rozwijania już istniejącej. Ukazanie zależności między innowacyjnością a kreatywnością powinno skutkować zmianami w systemie edukacji mającymi na celu pobudzanie kreatywności; powinno się to odbywać z wykorzystaniem nowych technologii. Szkoła jest czynnikiem rozwijającym kreatywność i wiedzę przyszłych pracowników. Kolejnym krokiem jest pokazanie możliwości przełożenia kreatywności na innowacyjność. W tym zakresie odpowiedzialność w dużej mierze spoczywa na organizacjach. Organizacje, korzystając z wiedzy i zdolności kreatywnych swoich pracowników, powinny zapewnić warunki do tworzenia innowacji.

\section{BIBLIOGRAFIA}

[1] Antoszkiewicz J.D., Antoszkiewicz E.A., Piech K., 2005, Kształcenie kreatywności w praktyce gospodarczej, [w:] K.J. Szmidt, K.T. Piotrowski (red.), Nowe teorie twórczości. Nowe metody pomocy w tworzeniu, Impuls, Kraków.

[2] De Bono E., 2011, Umysł kreatywny. 62 ćwiczenia rozwijające intelekt, Studio Emka, Warszawa.

[3] Dobro£owicz W., 2005, Dwa kierunki badania twórczości, [w:] W. Dobrołowicz, J. Gralewski (red.), Kreatywność: nowe aspekty poznawcze i praktyczne, Wszechnica Polska - Szkoła Wyższa Wiedzy Powszechnej, Warszawa.

[4] BrzezińsKi M., 2009, Organizacja kreatywna, Wydawnictwo Naukowe PWN, Warszawa.

[5] Castells M., 2008, Społeczeństwo sieci, Wydawnictwo Naukowe PWN.

[6] Daniecki W., 2015, Talenty w firmie, czyli jak rekrutować i motywować najlepszych, Wydawnictwo Naukowe PWN, Warszawa.

[7] ERIKsen T.H., 2003, Tyrania chwili, Państwowy Instytut Wydawniczy, Warszawa.

[8] KąKol U., Krupa A., Kosieradzka A., Smagowicz J., 2013, Proste metody pobudzania kreatywności, [w:] A. Kosieradzka (red. nauk.), Metody i techniki pobudzania kreatywności w organizacji i zarządzaniu [e-book], edu-Libri, Kraków.

[9] NęCKa E., 2005a, Psychologia twórczości, Gdańskie Wydawnictwo Psychologiczne, Gdańsk.

[10] N̨̨CKa E., 2005b, Trening twórczości, Gdańskie Wydawnictwo Psychologiczne, Gdańsk.

[11] Prelipcean G., 2000, Creativity in Business and Education - Useful Ideas for Managers, [w:] J. Szczecińska (red.), Creativity in business and education, Wydawnictwo Wyższej Szkoły Humanistyczno-Ekonomicznej, Łódź.

[12] Proctor T., 2000, Zarządzanie twórcze, Felberg SJA, Warszawa.

[13] Proctor T., 2003, Twórcze rozwiazywanie problemów, Gdańskie Wydawnictwo Psychologiczne, Gdańsk.

[14] Ridderstråle J., Norsdström K.A., 2006, Karaoke capitalizm. Zarządzanie dla ludzkości, Wydawnictwo Helion, Gliwice.

[15] Sloane P., 2005, Twórcze myślenie w zarządzaniu, Gdańskie Wydawnictwo Psychologiczne, Gdańsk. 
[16] StanisŁaWiak E., 2013, Możliwości i ograniczenia w kształtowaniu postaw twórczych, [w:] A. Kosieradzka (red. nauk.), Metody i techniki pobudzania kreatywności w organizacji i zarządzaniu [e-book], edu-Libri, Kraków.

[17] Szmidt K.J., 2013, Trening kreatywności. Podręcznik dla pedagogów, psychologów i trenerów grupowych, Wydawnictwo Helion, Gliwice.

[18] Szopiński J., 2013, Psychologiczne podstawy kreatywności, [w:] A. Kosieradzka (red. nauk.), Metody i techniki pobudzania kreatywności $w$ organizacji i zarządzaniu [e-book], edu-Libri, Kraków.

[19] Szopiński T., 2013, Kreatywność i jej znaczenie w biznesie, [w:] A. Kosieradzka (red. nauk.), Metody i techniki pobudzania kreatywności w organizacji i zarządzaniu [e-book], edu-Libri, Kraków.

[20] TAYlor C.W., 1988, Various approaches to and definition of creativity, [w:] R.J. Sternberg (red.), The Nature of Creativity: Contemporary Psychological Perspective, Cambridge University Press, Cambridge.

[21] Tokarz A., 2005, Motywacja jako warunek aktywności twórczej, [w:] A. Tokarz (red.), W poszukiwaniu zastosowań psychologii twórczości, Wydawnictwo Uniwersytetu Jagiellońskiego, Kraków.

[22] West M.A., 2000, Rozwijanie kreatywności wewnątrz organizacji, Wydawnictwo Naukowe PWN, Warszawa.

[23] Zimbardo P.G., Gerrig R.J., 2009, Psychologia i życie, Wydawnictwo Naukowe PWN, Warszawa.

\section{NETOGRAFIA}

[1] Amabile T.M., 2012, Componential Theory Of Creativity, „Working Paper”, 12-096, Harvard Business School, http://www.hbs.edu/faculty/Publication\%20Files/12-096.pdf (29.06.2016).

[2] Amabile T.M., Pillemer J., 2011, Perspectives on the Social Psychology of Creativity, „Journal of Creative Behavior", 46(1), Harvard Business School, https://dash.harvard.edu/bitstream/handle/1/9349326/Perspectives_Soc\%20Psych\%20of\%20Cre_Amabile-Pillemer_JCB_v07_12\%20 11\%2011.pdf? sequence=2 (28.06.2016).

[3] Burski J., ChŁoń-Domińczak A., Palczyńska M., Rynko M., Śpiewanowski P., 2013,_Umiejętności Polaków - wyniki Międzynarodowego Badania Kompetencji Osób Dorostych (PIAAC), Instytut Badań Edukacyjnych, Warszawa, http://produkty.ibe.edu.pl/docs/raporty/ibe-raport-PIAAC-2013.pdf (28.06.2016).

[4] Gmurczyк J., 2014, Innowacyjność polskiej gospodarki. Stan obecny i rekomendacje, Instytut Obywatelski, http://www.instytutobywatelski.pl/wp-content/uploads/2014/04/Analiza_Innowacyjno\%C5\%9B\%C4\%87_27-02.pdf (22.06.16).

[5] Karwowski M., Jankowska D.M., 2015, Czy polska szkoła nie lubi twórczych uczniów?, [w:] R. Dolata, P. Grygiel, D.M. Jankowska, E. Jarnutowska, A. Jasińska-Maciążek, M. Karwowski, M. Modzelewski, J. Pisarek, Szkolne pytania. Wyniki badań nad efektywnością nauczania w klasach IV-VI, Instytut Badań Edukacyjnych, Warszawa, https://www.nck.pl/badania/raporty/-szkolne-pytania-wyniki-badan-nad-efektywnoscia-nauczania-w-klasach-iv-vi (7.07.2016).

[6] KOMISJA EUROPEJSKA, 2016a, https://ec.europa.eu/poland/news/160714_innovations_pl (17.07.2016).

[7] KOMISJA EUROPEJSKA, 2016b, http://europa.eu/rapid/press-release_MEMO-16-2487_en.htm (18.07.2016).

[8] KOMISJA WSPÓLNOT EUROPEJSKICH, 2006, Komunikat Komisji do Rady, Parlamentu Europejskiego, Europejskiego Komitetu Gospodarczo-Społecznego i Komitetu Regionów - Wykorzystanie 
wiedzy w praktyce: szeroko zakrojona strategia innowacyjna dla UE, http://eur-lex.europa.eu/ legal-content/PL/TXT/?uri=CELEX\%3A52006DC0502 (24.06.2016).

[9] KOMISJA WSPÓLNOT EUROPEJSKICH, 2008, Komunikat Komisji do Rady, Parlamentu Europejskiego, Europejskiego Komitetu Gospodarczo-Społecznego i Komitetu Regionów - Rozwijanie kompetencji na miarę XXI wieku: plan europejskiej współpracy w zakresie szkół, http://eur-lex. europa.eu/legal-content/PL/TXT/?uri=CELEX\%3A52008DC0425 (23.06.2016).

[10] KOMISJA WSPÓLNOT EUROPEJSKICH, 2009, Komunikat Komisji do Rady Parlamentu Europejskiego, Europejskiego Komitetu Ekonomiczno-Społecznego i Komitetu Regionów - Inwestowanie w młodzież i mobilizowanie jej do działania: strategia UE na rzecz młodzieży. Odnowiona otwarta metoda koordynacji na potrzeby wyzwań i możliwości stojących przed młodzieżą, https://eur-lex. europa.eu/legal-content/PL/TXT/?qid=1535365876374\&uri=CELEX:52009DC0200 (25.06.2016).

[11] MINISTERSTWO GOSPODARKI, 2015, Polska 2015. Raport o stanie gospodarki, https://www. miir.gov.pl/media/15346/Raport_o_stanie_gospodarki_2015_pl.pdf (12.09.2016).

[12] Niedzielski P., Rychlik K., 2007, Kreatywność a rozwój technologii informacyjnych - nowe obszary innowacyjności, „Zarządzanie zasobami ludzkimi”, nr 1/2007, https://www.ipiss.com.pl/ wp-content/uploads/downloads/2012/11/p_niedzielski_k_rychlik_zzl_1_2007.pdf (24.06.2016).

[13] SudAK I., 2016, Krynica 2016. Premier Beata Szydło wspiera polskie start-upy. „Musimy być lepsi od innych”, „Gazeta Wyborcza”, http://wyborcza.biz/biznes/1,147752,20655672,krynica-2016-premier-beata-szydlo-wspiera-polskie-startupy.html (12.09.2016).

[14] Zadura-Lichota P. (red.), 2015, Innowacyjna przedsiębiorczość w Polsce. Odkryty i ukryty potencjał polskiej innowacyjności, Polska Agencja Rozwoju Przedsiębiorczości, Warszawa, http:// www.parp.gov.pl/files/74/81/806/22522.pdf (21.06.2016). 
